\title{
The use of cartoons in teaching commercial English
}

Pauline Tee Anderson

\section{(2) OpenEdition}

\section{Journals}

Édition électronique

URL : http://journals.openedition.org/asp/3653

DOI : 10.4000/asp.3653

ISSN : 2108-6354

\section{Éditeur}

Groupe d'étude et de recherche en anglais de spécialité

\section{Édition imprimée}

Date de publication : 1 décembre 1996

Pagination : 341-350

ISSN : 1246-8185

\section{Référence électronique}

Pauline Tee Anderson, «The use of cartoons in teaching commercial English», ASp [En ligne],

11-14 | 1996, mis en ligne le 13 juillet 2013, consulté le 01 mai 2019. URL : http:// journals.openedition.org/asp/3653; DOI : 10.4000/asp.3653

Ce document a été généré automatiquement le 1 mai 2019.

Tous droits réservés 


\title{
The use of cartoons in teaching commercial English
}

\author{
Pauline Tee Anderson
}

1 When I saw that the theme of this year's GERAS symposium was experimentation et innovation(s), I felt that the way I teach commercial English to the students of Langues Etrangères Appliquées aux Affaires et au Commerce fitted in well with at least $50 \%$ of it, as I am experimenting with ways of integrating cartoons into my classes. However, I cannot claim that using cartoons in teaching languages in general -or even commercial English in particular - is either original or new, since a number of specialized manuals feature this type of material and some of them are approximately twenty years old.

2 The themes of the cartoons used in commercial English manuals are linked to the themes of the chapters they illustrate but, in general, their role seems to be purely decorative as they are not referred to directly. Presumably, they are included in order to give the student some much-needed light relief when working on arduous commercial topics. One exception to this is the manual The New Let's Talk Business! (Curin, Fedigan \& Granger 1977). In this method, each cartoon is accompanied by a 'Talking Point' consisting of either a topic for discussion or a suggestion for a role-playing activity. Moreover, a language note is included when the student may have difficulty understanding the caption.

3 My slight claim to innovation does not therefore lie in the fact that I use cartoons, but in the fact that I give them an extremely important role in certain classes. There are three main reasons for this. Firstly, pictures are a well-established teaching aid: they can be used to focus the attention of the class as a whole and they encourage reaction and therefore student participation; this is especially true in the case of cartoons since they often show improbable situations. Secondly, the importance of creating a pleasant learning environment and taking affective criteria into account has been stressed by a number of authors. Hutchinson and Waters (1987: 48), for instance, refer to the necessity of sweetening the medicine of relevance "with the sugar of enjoyment, fun, creativity" and cartoons can do exactly this. Thirdly, Ziv (1979) has shown that humour can facilitate learning if it is directly linked to the points being taught. 


\section{Course Content}

It should be mentioned here that students of Langues Etrangères Appliquées are among those ESP students who have a limited knowledge of the specific purpose which they are learning English for. In fact they have a particularly unusual status since they are language students first and business students second. This point affects course content and is also crucial in my use of cartoons, i.e. as a teaching aid not only to introduce or reactivate commercial vocabulary, but also to familiarize students with the business world in Britain and to help them understand certain concepts.

The courses I give to second- and third-year students are organized as follows. One aspect is commercial correspondence, which is often seen as a 'necessary evil' by both teachers and students of commercial English. I have dealt with this difficulty -and also alleviated the problem of lack of time- by having my students acquire this skill on their own using my manual Business letters; enjoyment is the key word here as most of the exercises are based on crossword puzzles and games. I check on the students' progress at regular intervals but the vast majority of class time is devoted to looking at various business topics, for which I have compiled a series of booklets. These consist of general explanations to introduce key vocabulary, as well as articles, exercises - again featuring a 'play' approach in many cases - and cartoons. The work carried out in the second-year course is backed up by Thème commercial classes in which I use texts covering the same topics and therefore the same lexical fields, and the students also follow courses in Version économique, Thème grammatical, Civilisation and oral English.

The subjects covered in the booklets mentioned are shown in Figure 1. The first level deals with people and organizations; my aim here is to try to interest students in how people work and how various institutions function in Britain and, to a lesser extent, the United States. The second level is concerned with products and importing and exporting them, and is therefore more technical.

\section{Availability of Cartoons}

7 My main source of cartoons to illustrate these topics is a paper called The Weekly News. It contains a large number of cartoons of a very general nature, by which I mean that they are not political or based on current events. However, they do reflect social trends and people's concerns (divorce, unemployment, the Lottery, etc.) and it is for this reason that a considerable number deal with people's working lives and the organizations that most members of the public come into contact with. Figure 2 indicates how my initial collection of 389 business cartoons from this paper can be categorized into the topics listed in Figure 1.

Figure 1: Business topics studied -2nd and 3rd year courses - Langues Étrangères Appliquées

\begin{tabular}{|l|l|}
\hline Level 1 - 2nd year & Level 2 - 3rd year \\
\hline The World of Work & Channels of Distribution \\
\hline
\end{tabular}




\begin{tabular}{|l|l|}
\hline Office Work and Equipment & The Sale and Purchase of Goods \\
\hline The Organization of a Firm & Packing and Packaging \\
\hline Forms of Business Organization and the Stock Exchange & Means of Transport \\
\hline The Post Office and British Telecom & Insurance \\
\hline Banks and Banking & International Trade \\
\hline & Means of Payment \\
\hline
\end{tabular}

Figure 2: Breakdown of cartoons per topic (Total number. 389)

\begin{tabular}{|l|l|l|}
\hline Level & Topic & Number of cartoons \\
\hline 1 & The World of Work & 117 \\
\hline 2 & Channels of Distribution & 65 \\
\hline 1 & Office Work and Equipment & 40 \\
\hline 1 & Banks and Banking & 36 \\
\hline 1 & The Post Office and Telecommunications & 34 \\
\hline 1 & The Organization of a Firm & 32 \\
\hline 1 & Forms of Business Organization and the Stock Exchange & 15 \\
\hline 2 & Means of Payment & 11 \\
\hline 2 & The Sale and Purchase of Goods & 10 \\
\hline 2 & Packing and Packaging & 10 \\
\hline 2 & Insurance & 6 \\
\hline 2 & Means of Transport & 5 \\
\hline 2 & International Trade & 8 \\
\hline
\end{tabular}

This table shows that Channels of Distribution is the only Level 2 topic for which a large number of cartoons is available. This is because of the more technical nature of the second level: cartoons do not tend to mention incoterms, bills of lading or documentary credits. There are ways of incorporating them into quite technical subjects like these, as will be described below, but cartoons have a more important role in Level 1. In this level, I use them to introduce or illustrate the various subjects studied and to encourage the students to express their knowledge of and opinions on accessible topics that they do know about. This limits the problem of the learner being placed in the doubly inferior 
position described by Isani (1993) - i.e., as concerns subject matter as well as the language used for it.

\section{Some examples of use}

9 Originally, I used cartoons in the same way as most of the commercial English manuals mentioned above, namely to make the booklets more attractive. This is a perfectly valid approach so I still include some in the booklets themselves; however, I now show others on an overhead projector.

10 As previously stated, I choose the cartoons not only for vocabulary but also for the ideas behind them. Very often, the same cartoons can serve both purposes, which is the case with cartoon no 1 (see Appendix). ${ }^{1}$ This can be included in a class at the beginning of Level 1; it should immediately produce a few smiles as it is not difficult to understand. I would encourage students to talk about their ideas before going into details, in which case the following teacher-student exchange can be envisaged:

$\mathrm{T}$ : Why isn't the man looking very pleased?

S: He doesn't want a skateboard. /He's too old to use a skateboard...

T: What transport would he prefer to have?"

S: A car.

T: Do you think he'll apply for the job?

S: No, he's not interested in what the firm's offering. / Perhaps. The salary's very

good and he may be unemployed.

11 If the pay is mentioned, it is a point to be pursued. Just how good is the salary? Students will probably think that the figure given is the monthly salary, so 'PA' can be explained and it can be added that, in Britain, it is always the annual salary that is indicated in advertisements and contracts of employment. This should prevent a mass exodus across the Channel.

$\mathrm{T}$ : Where is he?

S: In a job centre or an agency.

$\mathrm{T}$ : What else could he do to find a job?

S: Look in newspapers. / Write to firms. / ...

$\mathrm{T}$ : What else could he receive in addition to his salary?"

S: Commission/Cheap toys / ....

The degree of sophistication of the students' vocabulary will depend on whether the cartoon is shown to introduce the above points or to reactivate items that have already been taught. I believe that the possible answers I have given are realistic even if the cartoon is used as an introduction except that, in this case, the reply to the question "Where is he?" could well be "At the ANPE."

As far as lexical content and other teaching points are concerned, this cartoon is very rich even though the gentleman depicted does not actually say anything. When considering the vocabulary, the items that can be introduced as a result of the terms actually used in the cartoon -and of the ideas behind it- should also be taken into account. (Figure 3)

14 As a follow up, it is possible to encourage creativity by showing a cartoon with an incomplete caption (2a) before revealing the full version (2b). Moreover, it is possible to be even more ambitious and hide the whole caption (3a). Here, students could well put forward suggestions like "I don't need to wash mine" or "I don't use any petrol" but in view of the context in which the cartoon is presented, it is quite possible that someone 
will mention company cars or vehicles (3b). However, whether the 'right' answer is given is secondary to the fact that the students have an opportunity to use their imagination.

Figure 3: 'Skateboard cartoon - Teaching points

\begin{tabular}{|c|c|}
\hline ITEMS IN THE CARTOON & EXTENSIONS \\
\hline vacancies & situations vacant (in the press) \\
\hline rep, salesman & $\begin{array}{l}\text { representative, sales rep(resentive); sales assistant, shop } \\
\text { assistant; seller }{ }^{2}\end{array}$ \\
\hline sales & $\begin{array}{l}\text { purchases } \\
\text { to sell to - to buy / purchase from }\end{array}$ \\
\hline position of $£$ sign & - \\
\hline 15,000 & 15.865 \\
\hline P.A. / p.a. (per annum) & P.A. (personal assistant) \\
\hline $\begin{array}{l}\text { IDEAS BEHIND THE } \\
\text { CARTOON }\end{array}$ & $\begin{array}{l}\text { company car, company vehicle } \\
\text { job centre } \\
\text { employment agency } \\
\text { fringe benefits, perks }\end{array}$ \\
\hline
\end{tabular}

A large number of cartoons are based on company cars, which indicates their importance in Britain, and showing one of them is an opportunity to mention this fact of business life. They are status symbols in large companies as there are usually strict rules about which category of executives can have which type of car.

the 'skateboard' cartoon is used as a starting point, the theme of the lesson can be continued in two ways: job-hunting or fringe benefits and, possibly, motivation of staff.

17 It is not difficult to find cartoons on job-hunting (4). Here, the role of job centres can be discussed and this can lead on to private employment agencies and even management consultants. Cartoon no 5 illustrates the fact that jobs are sometimes advertised on the premises of the organization concerned. The terms 'apply', 'applicant' and 'application' can be taught or revised.

Hopefully, students should be able to continue with their suggestions for finding jobs. A natural progression from this would be to go on to interviews, which are also shown in a lot of cartoons and about which students should have plenty to say.

If the theme of fringe benefits is to be pursued, again it is quite easy to find appropriate cartoons. If cartoon no 6 is shown, it can be mentioned that the staff canteen may well be subsidised or, if there is no canteen, that staff may be given luncheon vouchers. The advantages for the employer of the staff eating properly at midday can also be discussed, as can the contrast between British / French eating habits during the day. Moreover, it is possible to do a little revision and ask the question, "What does this man do?", to which 
the answer will hopefully be "He's a salesman" or "He's a shop assistant" and not "He's a seller" or even "He's selling shoes".

In cartoon no 7, which shows an extremely important fringe benefit for British workers, the term itself is actually used. In mentioning the importance for British staff, I was, of course, referring to the tea and coffee available from the machine. Again, students should be able to continue the discussion by adding other possible perks, either from their own experience or their parents' or friends'.

21 As mentioned earlier, it is more difficult to find cartoons on the more technical subjects studied in Level 2, but there are usually some that can be used, for example no 8 . The relevance of this situation may not be immediately obvious but, in fact, this cartoon illustrates the provisions of the Sale of Goods Act, which comes into 'The Sale and Purchase of Goods'. It is an example of a cartoon that can be used to help students apply their theoretical knowledge, in which case the following exchange is possible:

$\mathrm{T}$ : Who is the man speaking to?

S: Someone in the shop where he bought the raincoat.

T: That's right. It's the retailer who has to deal with this sort of problem, not the....

S: Manufacturer.

$\mathrm{T}$ : What can he ask the retailer for?

S: His money back. / A refund

$\mathrm{T}$ : What if he's offered a credit note?

S: He doesn't have to accept it. The raincoat isn't of merchantable quality.

T: Why not?

S: Goods sold have to be free of faults and able to do their job."/"A raincoat has to

be waterproof.

$\mathrm{T}$ : Is he entitled to any compensation?

S: If his other clothes have been damaged, yes.

T: Have you ever had this kind of problem?, etc.

Similarly, cartoon no 9 can be used to elicit ways in which exporters can ensure that they receive payment from their customers abroad. Such a discussion would involve the students using quite technical terms.

In the examples I have shown so far, the humour of the cartoons has been based on incongruous situations or amusing aspects of life (we all roar with laughter at the idea of women taking hours to choose their shoes, for instance). Most of the 389 cartoons mentioned come into these categories but some play with language. Very often, students do not 'get' such cartoons immediately and special care has to be taken when using them. Students should not have any difficulty in recognising the homophone 'mail/male' used in no 10 but some explanation of the postal system in Britain will be necessary for them to understand what second class mail is (or, alternatively, they can be encouraged to guess). This, in fact, would be the reason for using the cartoon.

Cartoons based on homonyms can also be extremely useful as they give students practice in recognising that words do not always have the same meaning just because they look the same. However, if neither of the meanings on which the humour is based is known, the result is likely to be complete confusion. For this reason, I would suggest not using cartoon no 11 until students are familiar with the terms 'training' and 'course'. Most will probably interpret the cartoon to mean that there is doubt as to whether the production manager is following a training course or a golf course, i.e., un stage de golf, but there will no doubt be a few smiles even so. However, some should be able to work out the answer to the question, "What do you think the place where people play golf is called?" and the 
full hilarity of the joke will then be apparent to all. As well as the multiple meanings of the term 'course', the expressions 'to be on a course' or 'to be away on a course' can be highlighted.

Another form of verbal humour used in cartoons is to illustrate an expression or idiom in a literal way, as in numbers 12 and 13. These cartoons obviously give an opportunity to teach the expressions concerned as well as to encourage discussion of the situations depicted (door-to-door selling, for instance, which can lead on to a more general talk about selling methods). However, it is important to make it clear that it is not only window cleaners who start at the bottom and that you do not have to be a door-to-door salesman in order to get your foot in a door.

\section{Conclusion}

In this brief description of the practical aspects of using cartoons, I have tried to show how such material can be integrated into classes on various business topics. In general, students react well to this approach and often make interesting -and unexpectedcomments on the cartoons they see. This is an extremely important point. A great deal is said about the learner's enjoyment but the teacher's should not be forgotten; with cartoons, it is possible for the students to become the entertainers, if only briefly.

It is also true, however, that the method has its limits: on the one hand, overexposing students to cartoons would defeat the object of enjoyment and, on the other hand, the teacher has to be prepared for a cartoon to fall flat. Nevertheless, on the whole, this is one area where business and pleasure can be successfully mixed. ${ }^{3}$

\section{BIBLIOGRAPHIE}

Curin, J., L. Fedigan \& A. Granger. 1970. Let's Talk Business! Tome 1. Paris: Hatier.

Curin, J., L. Fedigan \& A. Granger. 1977. The New Let's Talk Business! Tome 2. Paris: Hatier/Foucher. Daugeras, D. \& P. Janiaud-Powell. 1980. English for Business and Economics. Paris: Nathan.

Hutchinson, T. \& A. Waters. 1987. English for Specific Purposes, A learning-centred approach. Cambridge: Cambridge University Press.

Isani, S. 1993. "La langue de spécialité et le savoir disciplinaire : contrainte institutionnelle ou outil pédagogique de l'interaction ?". ASp 2, 199-208.

Jones, L. \& R. Alexander. 1989. International Business English. Cambridge: Cambridge University Press.

Nash, W. 1985. The Language of Humour, Style and Technique in Comic Discourse. London: Longman. Naterop, B., E. Weis, \& E. Haberfellner. 1977. Business Letters for All. Oxford: Oxford University Press. 
Tee Anderson, P. 1995. Business letters, exercices de présentation et de rédaction \& Business letters, corrigés des exercices. Paris: Les Éditions d'Organisation.

Ziv, A. 1979. L'humour en éducation, approche psycholoqique. Paris: Les Éditions ESF.

\section{ANNEXES}

All cartoons originally published in The Weekly News, (c) D.C.Thomson\&Co.,Ltd Dundee Scotland

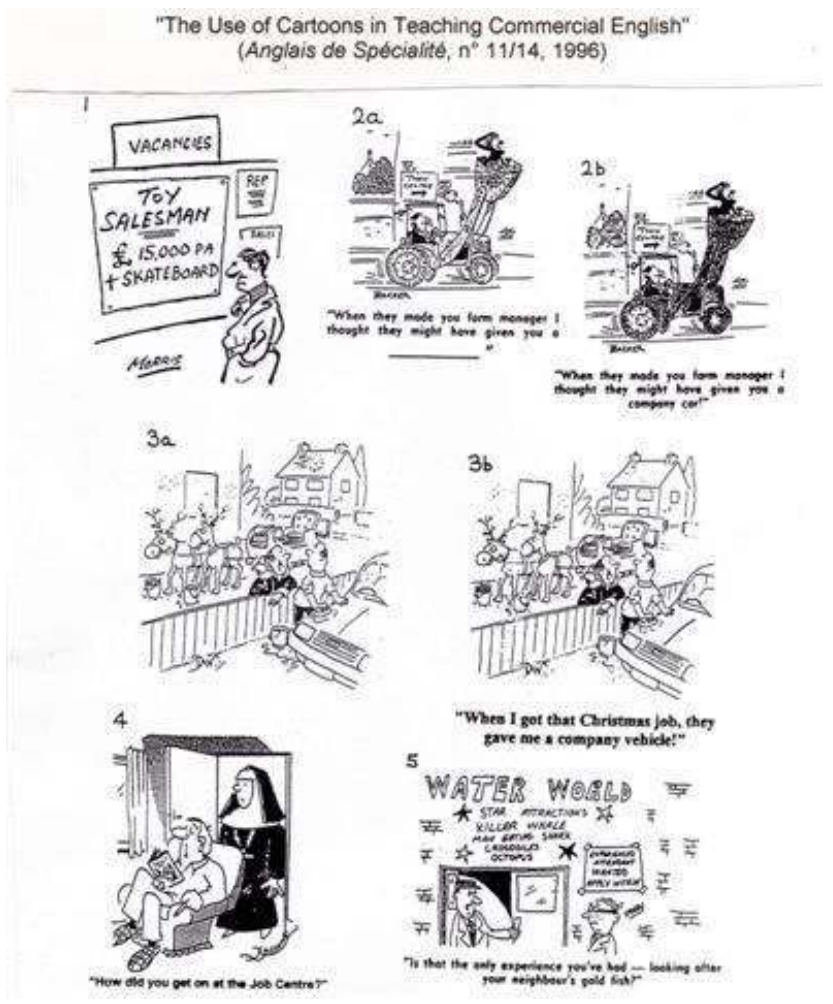




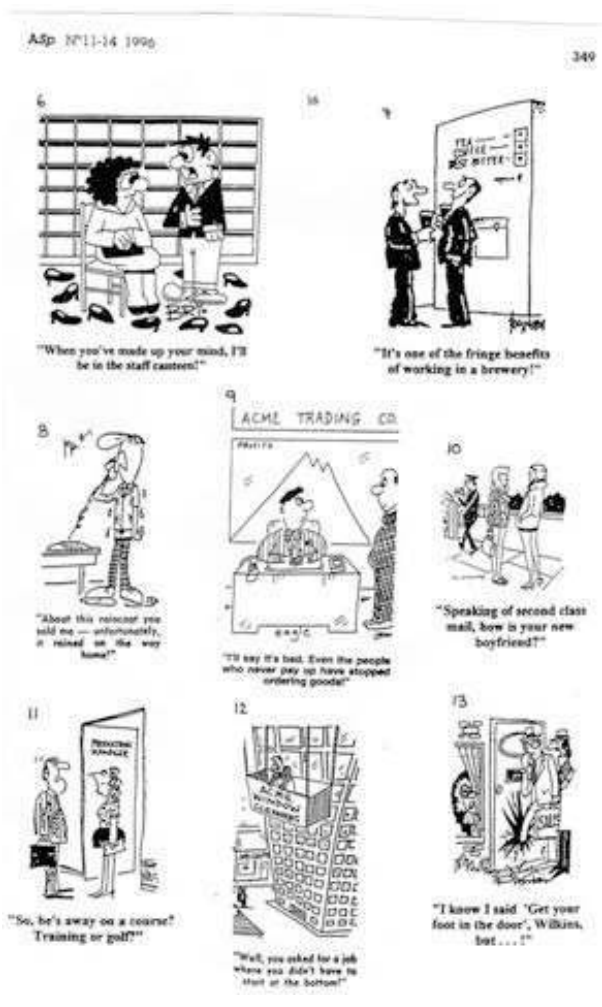

\section{NOTES}

1. The cartoons in the appendix will subsequently be referred to in one of the following ways: cartoon no., no. or a number in brackets.

2. Students tend to translate vendeur by 'seller' whatever the context. This cartoon gives an opportunity to point out that, in the majority of cases, sellers sell their own property and that there are usually other terms for people whose jobs consist of selling (sales assistant, etc.).

3. Postscript: The reactions of the class during the presentation of this paper would seem to confirm two of the points made above. Firstly, cartoons can be used to encourage creativity: numerous suggestions were made for completing cartoon $2 \mathrm{a}$ and for a caption for $3 \mathrm{a}$ (e.g., "I don't need snow tyres"). Secondly, my claim that cartoons can generate an agreeable learning environment was borne out by the extremely pleasant atmosphere in the group, on which several participants commented.

\section{RÉSUMÉS}

L'importance de critères affectifs dans l'apprentissage d'une langue étrangère a conduit à la mise au point d'activités ludiques destinées à augmenter le plaisir de l'apprenant. Les dessins humoristiques font partie des documents qui peuvent s'utiliser dans la didactique de l'anglais commercial: non seulement pour développer les compétences linguistiques ainsi que les 
connaissances des affaires des étudiants, mais aussi pour encourager leur participation et leur créativité. L'approche utilisée dépend en partie du type d'humour concerné.

The importance of affective criteria in foreign language learning has led to the development of teaching methods that incorporate activities designed to increase enjoyment. Cartoons come into this category and can be used in commercial English courses: they not only make a serious contribution to the student's linguistic skills and background knowledge, but also encourage participation and creativity. The approach used partly depends on the type of humour involved.

INDEX

Keywords : cartoon, commercial English, creativity, enjoyment, LEA, participation

Mots-clés : anglais commercial, créativité, dessin humoristique, LEA, participation, plaisir

\section{AUTEUR}

\section{PAULINE TEE ANDERSON}

Pauline Tee Anderson is a Senior Lecturer at Département LEA, Université de Perpignan. a nderson@univ-perp.fr 